Journal of Educational Method and Technology Vol. 1 No. 2, September 2018

P-ISSN 2622-8459 E-ISSN 2622-8467

http://ejournal.unima.ac.id/index.php/jemtec

\title{
Infix in Tolour Language
}

\author{
R C. Paath ${ }^{1}$ \\ ${ }^{1}$ Universitas Negeri Manado, Indonesia \\ corresponding author: ${ }^{1}$ ruthpaat@unima.ac.id
}

\begin{abstract}
This research is aimed to describe: 1) Form of Infix \{um- $\}$ in Tondano dialect of Tolour Language, 2) in-the function of infix $\{$-um- $\}$ in Tondano dialect of Tolour Language, 3) the meaning of infix $\{$-um- $\}$ in Tondano dialect of Tolour Language. This research used quantitative methods. Data collection technique used for this research was trigger (basic technique) and interview (advance technique). Resea2rcher used list of questions that were related to infix problem in Tolour Language. Other than that, in obtaining supporting data, 3 (three) informants from Seretan Village were chosen. Ata analysis technique was undertaken by identifying finding of interview, combined to data from written source. The next step, the data of kind were classified and analyzed according to its form, function and the meaning, the cause of the attachment of infix in the basic form. At the end, the finding from data analysis showed that infix arrangement $\{-u m-\}$ at the basic form had experienced changes. The forms of infix $\{-\mathrm{um}-\}$ in Tondano dialect of Tolour Language cover: (1) if it was attached to the basic form which has vocal ( $\mathrm{a}, \mathrm{i}, \mathrm{u}, \mathrm{e}, \mathrm{o})$, so the assimilation and position change would happen, (2) if it was attached to the basic form preceded by bilabial phoneme /p,w/, change would happen which was infix $\{-\mathrm{um}-\}$ would move prefix position and the first phoneme in its assimilated form, (3) if it was attached to the basic preceded by consonant phoneme, there would be no change. Infix $\{-u m-\}$ is aimed to form transitive and intransitive verb from basic forms of varied categories either pre-category, nominal, adjective, and numerical. He purpose of infix attachment in its basic form changed according to the purpose of the basic from attached, which (1) means an action that would happen, (2) determines the purpose of an continuous action that related to what is said in the basic form, (3) determines the meaning of becoming like it in the basic form, and (4) determines the meaning of would become as said in the basic form.
\end{abstract}

Keywords: Infix, Tolour Language. 
Journal of Educational Method and Technology Vol. 1 No. 2, September 2018

P-ISSN 2622-8459 E-ISSN 2622-8467

http://ejournal.unima.ac.id/index.php/jemtec

\section{Introduction}

Tolour language is one of traditional languages in Minahasa which was used as a tool of communication by the society who lived there or the society who are not staying there anymore yet are from the land of Tolour. Although the temporary observation showed that the situation of the use of Tolour language start losing its genuineness. The frequency of its use was decreasing. Moreover, the use of the language by young generation had almost been replaced by Melayu Manado language by which dominates the society in varied situation of its use.

Observing the use of Tolour language these days which need to be concerned especially several places (villages) where stayed the native speaker of this language, the native had tendency to use Melayu Manado language as communication tool in daily activities, so it was considered important to have a step of anticipation, either by the government or other social agencies, and one of its realization was by conducting research.

This research was focused to the forming of word (morphology) of Tondano dialect of Tolour language, especially infix observed from the aspect of form, function, and meaning morphologically in Tolour language. This relates to linguistic development of this nation.

This research was expected to positively contribute to linguistic research and development in this nation. Would be able to assist the Government of Indonesia through Language Agency to cultivate and to develop traditional languages to preserve Indonesian Language. As well as the native speaker nowadays were developed by the implementation of Local Content subject for students.

1. Problem

The problem of this research was formulated as follows:

a. How was infix $\{-u m-\}$ in Tondano dialect of Tolour language?

b. How did infix $\{-u m-\}$ function in Tondano dialect of Tolour language?

c. How did infix $\{$-um- $\}$ deliver its definition in Tondano dialect of Tolour language?

2. Purpose of the study

This research was aimed to:

a. describe the form of infix $\{-\mathrm{um}-\}$ in Tondano dialect of Tolour language.

b. describe the function of infix $\{-\mathrm{um}-\}$ in Tondano dialect of Tolour language.

describe the definition/meaning of infix $\{-\mathrm{um}-\}$ in Tondano dialect of Tolour language.

\section{Literature Review}

Infix, is an affix which was placed in the middle of a word (Muslich, 2010:13). Because it sticks in the middle of a word so it was called infix, not all language through out the world aware of infix. Languages in Indonesia especially 
Journal of Educational Method and Technology Vol. 1 No. 2, September 2018

P-ISSN 2622-8459 E-ISSN 2622-8467

http://ejournal.unima.ac.id/index.php/jemtec

that were already influenced by Philipine emerged and had system. Infix in Indonesian language was not productive for it had 3 (three) types on infix: (-er-), (-el-), and (-em-).

The examples of infix in Indonesian language:

-er- : -er- + gigi $\rightarrow$ gerigi

-el- : $\quad$ el- + tunjuk $\rightarrow$ telunjuk.

-em- : -em- + guruh $\rightarrow$ gemuruh

Basically, the form of infix was not a free-form construction for the form was bound that would only have the meaning if only it already attached to other form. Therefore, infix was a grammatical unit that was placed in the middle of the word.

\section{Research Methodology}

This research oriented on the qualitative descriptive approach. According to Maelong (1989:9) in qualitative research, data would be collected in words, picture and not number, besides, all data had possibility to be the key toward what is observed. Linguistic Method (Sudaryanto 1992; Kdidalaksana 1992; ad Mashun 2013). According to Sudaryanyo (1992) a fine method was the conversation between the researcher and the native speaker as an information source.

Research Technique

Data collection technique used was trigger (basic technique) and conversation (advanced technique). The research would use the provided questionnaire that related to infix problem in Tolour language.

\section{Technique of Data Analysis}

Data analysis was undertaken by identifying the result of interview, combined to other data from written form. Next step was to classify all data in the same kind and to analyze according to the form, function and meaning/definition raised by the process of attachment of the infix to the basic form. At the last step, describe the finding.

\section{Data Source}

According to Danie (1980:205) Tolour language consists of 4 dialect, those are :

1) Tondano dialect,

2) Kakas dialect,

3) Remboken dialect, and

4) Kampung Jawa Tondano Dialect

Looking up to the usage of Tolour language, the researcher focused this study to Tondano dialect. Tondano dialect is used as communication tools by the society in Tolour territory that spread along several sub-district which are : north Tondano, west Tondano, south Tondano, Remboken, Kakas, east Lembean, Eris and Kombi. 
Data resource was taken from several written source such as : lore, Tondanonesse dictionary, and all those outcomes from the research that have relation with the infix of Tolour language. In addition, to be able to have the supporting data, there had been decided three (3) Informants based on the qualifications of Mahsun (2005:95) :

\section{Data analysis and study}

1. Infix form $\{$-um- $\}$

On the explanation below, we can see the effect of adding infiks $\{-$ um- $\}$ for the basic form, then it establishes the changes of the infix form itself.

1) Infix / -um- / if it is added to the basic form which its first phoneme is $\operatorname{vocal}(\mathrm{a}, \mathrm{i}, \mathrm{u}, \mathrm{e}, \mathrm{o})$, it will create assimilation and movement of position.

(a ) Infix / -um- / if it is added to the basic form which its first phoneme is /a/ will create the change. The change of /-um-/ which is phoneme /u/ disappears or assimilates and phoneme $/ \mathrm{m} /$ moves to the prefix position. At the end of the first syllable happens glottal.

Example:

$/$-um- / + / alung / $\rightarrow$ / ma?lung / ' wil intercept ' /-um- $/+/$ ape $/ \rightarrow /$ ma?pe / ' will block'

Infix /-um-/ if it is attached to the basic form which its first phoneme is /i/ will have a change. The change of /-um-/ which phoneme /u/ disappears or assimilates and phoneme $/ \mathrm{m} /$ moves to the prefix position. At the end of first syllable happens glottal.

Example :

/ -um- / + /ibor/ $\rightarrow$ / mi?bor/ / ' will dip '

/ -um- / + / intuk / $\rightarrow$ / mi?ntuk / "will bark "

Infix /-um-/ if it is attached to the basic form which its first phoneme is /u/ will have a change. The change of /-um-/ which phoneme /u/ disappears or assimilates and phoneme $/ \mathrm{m} /$ moves to the prefix position. At the end of first syllable happens glottal.

Example :

/ -um- / + /usek / $\rightarrow$ / mu?sek/ / ' will dip ‘

/ -um- / + uwak / $\rightarrow$ / mu?wak / ' will joke '

(d) Infiks /-um-/ if it is attached to the basic form which its first phoneme is /e/ will have a change. The change /-um-/ which is phoneme /u/ disappears or assimilates and phoneme $/ \mathrm{m} /$ moves to prefix position. At the end of the first syllable happens glottal.

Example :

/ -um- / + / elot / $\rightarrow$ / me?lot / "will cure "

/ -um- / + / erur / $\rightarrow$ / me?rur / ' will collect ' Infiks /-um-/

if it is attached to the basic form which its first phoneme is /o/ will have a change. The change /-um-/ which is phoneme /u/ disappears or assimilates and phoneme $/ \mathrm{m} /$ moves to prefix position. At the end of the first syllable happens glottal.

Example :

/ -um- / + /oas / $\rightarrow /$ mo?as / "will wash ‘ 
Journal of Educational Method and Technology Vol. 1 No. 2, September 2018

P-ISSN 2622-8459 E-ISSN 2622-8467

http://ejournal.unima.ac.id/index.php/jemtec

/ -um- / + / oyow / $\rightarrow$ / mo?yow / ' will swim '

Infiks /-um-/ if it is attached to the basic form which its first phoneme is $/ \mathrm{p}, \mathrm{w} /$ will have a change.

(a). Infiks /-um-/ if it is attached to the basic form which its first phoneme is /p/ will have a change. The change /-um-/ which is phoneme /u/ disappears or assimilates and phoneme $/ \mathrm{m} /$ moves to prefix position and the first phoneme of the basic form assimilates.

Example :

/ -um- / + / paras / $\rightarrow$ / maras / "will cut off '

/ -um- / $+/$ pa?sek / $\rightarrow /$ ma?sek / ' will implant '

(b). Infiks /-um-/ if it is attached to the basic form which its first phoneme is /w/ will have a change. The change /-um-/ which is phoneme /u/ disappears or assimilates and phoneme $/ \mathrm{m} /$ moves to prefix position. The first phoneme of the basic form assimilates.

Example :

/ -um- / + / wangker / $\rightarrow$ / mangker /' will sell '

/ -um- / + / wa?kes / $\rightarrow$ / ma?kes / ' will bind '

1. Infiks /-um-/ if it is attached to the basic form which is started by the consonant phoneme beside bilabial phoneme $/ \mathrm{m} /, \mathrm{p} / \mathrm{p}$ and $/ \mathrm{w} /$, will not change at all.

(a). Infiks /-um-/ if it is attached to the basic form which its first phoneme is $/ \mathrm{k} /$ will not have a change.

Example :

$$
\begin{aligned}
& \text { / -um- / + kelang/ / } \rightarrow \text { / kumelang / ' will walk' } \\
& \text { / -um- / }+/ \text { keret / } \rightarrow \text { / kumeret / 'will call ' }
\end{aligned}
$$

Infiks /-um-/ if it is attached to the basic form which its first phoneme is /I/ will not have a change.

Example :

/ -um- / + / linga / $\rightarrow$ / luminga / ' will listen '

/ -um- / + / ləpət / $\rightarrow$ / lumepet / " will fold '

Infiks /-um-/ if it is attached to the basic form which its first phoneme is $/ \mathrm{n} /$ will not have a change.

Example :

/ -um- / / naram / $\rightarrow$ / numaram / "will get use to "

/ -um- / + / ne?nep / $\rightarrow$ / nume?nep / ' wil swallow '

Infiks /-um-/ if it is attached to the basic form which its first phoneme is /r/ will not have a change.

Examplle :

/ -um- $/+/$ rengis / $\rightarrow$ / rumengis / "will burn '

$/$-um- $/+$ /redei / $\rightarrow$ / rumedei / " will stand up "

Infiks /-um-/ if it is attached to the basic form which its first phoneme is /s/ will not have a change.

Example :

/ -um- / + / saput / $\rightarrow$ / sumaput / 'will wrap ' 
Journal of Educational Method and Technology Vol. 1 No. 2, September 2018

P-ISSN 2622-8459 E-ISSN 2622-8467

http://ejournal.unima.ac.id/index.php/jemtec

/ -um- / + / sampet / $\rightarrow$ / sumampet/ ' will continue '

Infiks /-um-/ if it is attached to the basic form which its first phoneme is /t/ will not have a change.

Example :

/ -um- / + /tanem / $\rightarrow$ / tumanem / ' will plant '

/ -um- / + /tiboy / $\rightarrow$ / tumiboy / 'will hold'

2. The function of infix /-um-/

Infix /-um-/ functions to form transitive and intransitive verb from the basic forms of various category whether it is pre-categorical, nominal, adjectival, and numeral.

a) Transitive verb

Example :

/-um-/ + /edo/ $\rightarrow$ /me?do/ 'will take'

/-um-/ + /ka:n/ $\rightarrow$ /kuma:n/ 'will eat'

Example in the sentence :

/se me?do raren/

' they will take vegetables'

/kei kuma:n sera?/

'we are eating fish"

b) Intransitive verb

Example :

/-um-/ + /abut/ $\rightarrow$ /ma?but/ 'will objurgate '

/-um- $+/$ ke?ke?/ $\rightarrow$ /kume?ke?/ 'will laugh '

Example in the sentence :

/si mei ma?but/

'he/she came to objurgate'

/se kume?ke?/

' they will laugh'

Infix meaning of /-um-/

a) Infix /-um- / means an action that is still happening.

Example :

/ -um- / + redei / $\rightarrow$ / rumedei / ' will stand up/ will build up'

/ -um- / $+/$ todo / $\rightarrow$ / tumodo/ ' will push '

Example in the sentence :

/ se rumedei wale weru / " they will build up the new house "

/ ku tumodo noto / " will push the car"

b) on the basic form of nominal, infix /-um-/ tells the meaning of an acting process that relates to what has been told on the basic form itself.

Example :

/ -um- / + / awun / $\rightarrow$ / ma?wun / ' will create smoke '

/ -um-- / / lana / $\rightarrow$ / lumana / ' will be oily '

Example in the sentence :

/ napi ti?i ma?wun now / ' this fire will create smoke "

/sia si lumana eneuwak / ' she will cover up her body with oil / she will make her body oily ${ }^{6}$ 
Journal of Educational Method and Technology Vol. 1 No. 2, September 2018

P-ISSN 2622-8459 E-ISSN 2622-8467

http://ejournal.unima.ac.id/index.php/jemtec

c) on the basic for of adjectival, Infix /-um-/ tells the meaning of making like what has been told on the basic form.

Example :

/ -um- / + / oki? / $\rightarrow$ / mo'ki? / " will get smaller'

/ -um- / + item / $\rightarrow$ / mi?tem / 'will get dark'

Example in the sentence :

/Dano mo?ki/mow/ 'the stream of the water will get smaller'

kuli?na me?itemow / ' his/her skin will get dark '

d) On the basic form of numeral, Infix /-um-/ tells the meaning of wanting to be what habeen told on the basic form.

Example :

/ -um- / + esa / $\rightarrow /$ me?sa / "will be one "

$/$-um- $/+/$ rua / $\rightarrow$ / rumua / "will be two "

Example in the sentence :

/ se ma?sa waya / "they will be all ones '

/kei rumua pana:n / ' we both will have two palces to stay "

Example in sentences:

/se me?do raren/

'They will take vegetables'

/kei kuma:n sera?/

'Verbal transaction

Example:

/-um-/ + /abut/ $\rightarrow$ /ma?but/ 'will use'

/-um- +/ke?ke?/ $\rightarrow$ /kume?ke?/ 'will laugh'

Example in sentences:

/si mei ma?but/

'ia datang untuk memaki' He comes to course

/se kume?ke?/

'they will laugh'infix meaning/-um-/

a) Infix /-um-/ It means an action that will be existed.

Examples:

/ -um- / + /redei / $\rightarrow$ / rumedei / 'will stand'

/ -um- / + / todo / $\rightarrow$ / tumodo/ 'will be pushed'

Example in sentences:

/ se rumedei wale weru / 'they will build a new house'

/ ku tumodo noto / 'I will push a car'

(b) Basic form of nominal infix/-um-/ to state a meaning of an action related to the basic form mentioned.

Example:

/ -um- / + / awun / $\rightarrow$ / ma?wun / 'will smoke'

/ -um-- / + /lana / $\rightarrow$ / lumana / ' will be oiled'

Example in sentences:

/ napi ti?i ma?wun now / 'Fire will smoke'

/sia si lumana eneuwak / 'He will oiling his body'

(c) Basic form of adjective infix /-um-/ To state the meaning into basic form. 
Journal of Educational Method and Technology Vol. 1 No. 2, September 2018

P-ISSN 2622-8459 E-ISSN 2622-8467

http://ejournal.unima.ac.id/index.php/jemtec

Examples:

/ -um- / + / oki? / $\rightarrow$ / mo'ki? / 'Will be small'

/ -um- / / item / $\rightarrow$ / mi?tem / 'Will be black'

Example in sentences:

/Dano mo?ki/mow/ 'Water flow will be smaller'

/kuli?na me?itemow / 'The skin will turning black'

Basic form of numeralia infix /-um-/ To state the meaning that will be mentioned in to the basic form.

Examples:

$$
\begin{aligned}
& / \text {-um- } /+/ \text { esa } / \rightarrow / \text { me?sa / 'Will become one' } \\
& / \text {-um- / + / rua / } \rightarrow \text { / rumua / 'Will become two' }
\end{aligned}
$$

Example in sentences:

/ se ma?sa waya / 'They will become one'

/kei rumua pana:n / 'We will be two place of staying'

\section{Discussion}

According to hypothesis result above, it meant subject "English for Banking" had positive impact for students' readiness of Language and literature study program in field of work. After data analysis by questionnaire to the students can be concluded subject of "English for Banking" was given of English for banking vocabularies. It meant this subject was given to the students to provide them to have a chance to work bank.

After conducting this research, it can be concluded that subject "English for Banking" has positive impact toward students' readiness to work in bank. This subject is eligible to be applied in language and literature study program to adapt and work in bank.

\section{Conclusion}

Conclusion

a) The result of data analysis in infix system /-um-/ in basic form was changed. The forms of infix /-um-/ Tolour language includes: (1) If attached into basic vocal phonem (a, i, u,e, o), will be leaching and changed. (2) if attached into basic form started by phonem bilabial /p,w/ will be changed into infix /-um-/ move to prefix position and phonem to leach basic form, (3) If attached into basic form started by consonan phonem, will not change.

b) Infix Function /-um-/

Infix /-um-/ It's function to create transitive and intrasitive verbal into basic form into some categories pracategorial, nomina, adjectiva and numerlia.

c) In Tolour Language found some kinds of meaning causing by prefix attching /-um-/ into basic form. Those meaning changed according to basic meaning attached. (1) It means something that still exist. (2) To state 
Journal of Educational Method and Technology Vol. 1 No. 2, September 2018

P-ISSN 2622-8459 E-ISSN 2622-8467

http://ejournal.unima.ac.id/index.php/jemtec

meaning of a process related to basic form mentioned. (3) To state meaning become a basic form (4) to state meaning to become something mentioned in a basic form.

Suggestion

a) Tolour Langue is one of traditional language in Minahasa must has attention from native speaker, government, researcher to be continued.

b) It is hope for infix analysis /-um-/ Tolur language able to be passed by language researcher, because of this is limited reserach for basic prefix /um-/. Complex form is really important be analysis completely.

\section{References}

Amran, H. (editor) 1980. Politik Bahasa Nasional jilid I. Pusat Pembinaan dan Pengembangan Bahasa Departemen Pendidikan dan Kebudayaan, Balai Pustaka Jakarta.

Chaer, A. 2008. Linguistik Umum. Rineka Cipta.

----------- (2008). Morfologi Bahasa Indonesia. Pendekatan Proses. Penerbit Rineka Cipta.

Danie, J.A. 1980. Studi Dialek di daerah Minahasa Timur Laut. Bahasa Tonsea dan Sekitarnya. Pusat Pembinaan dan Pengembangan Bahasa Departemen Pendidikan dan Kebudayaan 1981.

Kridalaksana. (1992). Pembentukan kata dalam Bahasa Indonesia. PT Gramedia Pustaka Utama Jakarta.

Lyons,, J. (1968). Introduction to Theoretical Linguistics. Cambridge University Press Cambridge.

Mashun, M.S. (2013). Metode Penelitian Bahasa, Tahapan Strategi, Metode dan tekniknya, Rajawali Pers Jakarta.

Muslich M. (2007). Tata Bentuk BahasaIndonesia. Kajian Ke arah Tatabahasa Deskriptif .Bumi Aksara.

Moleong, L.J. (1989). Metodollogi Penelitian Kualitatif. Remadja RK Karya CV.

Nida, E.A. (1963). Morphology the Descriptive Analysis of Word. Ann Arbov University of Michigan Press.

Paath, R.C. (2003). Pemarkah Aspek Dalam Bahasa Tolour. Thesis Magister Linguistik, Program Pascasarjana Unsrat Manado.

Putrayasa I.B. (2008). Kajian Morfologi. Beuk Derivasional dan Infeksional. Refiko Aditama.

Samsuri. (2007). Analisis Bahasa. Erlangga Jakarta.

Sneddon, J.N. (1975) Tondano Phonology and Grammar. Departemen og Linguistics, the Australian National University. 
Journal of Educational Method and Technology Vol. 1 No. 2, September 2018

P-ISSN 2622-8459 E-ISSN 2622-8467

http://ejournal.unima.ac.id/index.php/jemtec

Sudaryanto. (1993). Metode dan Aneka Teknik Analisis Bahasa Pengantar Penelitian Wahana Kebudayaan secara Linguistis.Duta Wacana University Press Yogyakarta.

Sugerman. 2016. Morfologi Bahasa Indonesia. Kajian Ke Arah Linguistik Deskriptif. Penerbit Ombak.

Sugiyono. (2013). Metode Penelitian Kuantitatif dan Kualitatif. R\&D. Algabeta Bandung.

Verhaar. J.W.M. 1996. Asas-Asas Linguistik Umum. Yogyakarta: Gajah Mada University Press.

Wantalangi W.A. (1972). Kamus Bahasa Daerah Tondano-Indonesia 